\title{
ANALYZING THE AIRPORT PASSENGER EXPERIENCE: THE CASE OF CAIRO INTERNATIONAL AIRPORT
}

Hossam Samy Ahmed

The Egyptian Higher Institute for Tourism and Hotels, Cairo, Egypt

\begin{abstract}
This paper aims to analyze the key elements influencing the airport passenger experience at Cairo International Airport (CIA). The research confirmed that four main dimensions (the airport's services and facilities, access procedures, environment and personnel) have a significant positive effect on passengers' perception of the overall airport experience. The research proved that the airport's services and facilities is the most influential dimension of the passenger experience. The results also revealed that socio-demographic variables have a significant influence on passengers' impressions towards the overall airport experience. The paper confirmed that the airport customer care, airport ambiance, airport design, dining areas and staff efficiency are the primary elements of the passenger experience. Passengers' ratings of CIA were found to be below average in the most influential areas of the airport experience. The research concluded a number of recommendations that aim to enhance the overall passenger experience at CIA.
\end{abstract}

Key words: Airport experience, Cairo International Airport, Customer experience management, Customer journey, Passenger impression, Quality rating

Assoc. Prof. Dr Hossam Samy Ahmed: The Egyptian Higher Institute for Tourism and Hotels, Cairo, Egypt; Email: samyhossam2007@yahoo.com 


\section{INTRODUCTION}

Cairo International Airport (CIA) was inaugurated in the $18^{\text {th }}$ of May, 1963. It is the main hub for Egypt Air. The airport comprises three terminals, namely: Terminal 1 (the oldest facility), Terminal 2 (recently had its soft opening after undergoing major renovations), and Terminal 3 (the newest addition to the airport and the base for all Star Alliance members) (Cairo Airport Authority, 2017). The following table demonstrates the ranking of CIA among top Arab airports according to passenger traffic. The airport holds the $6^{\text {th }}$ positing among Middle Eastern airports.

Table 1: The Top Ten Arab Airports by Passenger Traffic-2015

\begin{tabular}{|c|c|c|}
\hline Rank & Airport & Passenger Traffic \\
\hline $\mathbf{1}$ & Dubai International & $78,010,265$ \\
\hline $\mathbf{2}$ & Hamad International Airport & $31,008,549$ \\
\hline $\mathbf{3}$ & King Abdul-Aziz International Airport & $29,010,429$. \\
\hline $\mathbf{4}$ & Abu Dhabi International Airport & $23,293,022$ \\
\hline $\mathbf{5}$ & Khalid International Airport & $22,656,457$ \\
\hline $\mathbf{6}$ & Cairo International Airport & $14,969,000$ \\
\hline $\mathbf{7}$ & Kuwait International Airport & $11,269,029$ \\
\hline $\mathbf{8}$ & Muscat International Airport & $10,315,358$ \\
\hline $\mathbf{9}$ & Sharjah International Airport & $10,039,936$ \\
\hline $\mathbf{1 0}$ & King Fahd International Airport & $9,526,026$ \\
\hline
\end{tabular}

Source: Airport Council International (2016)

Note: Latest available data

CIA is the second busiest airport in Africa, after Tambo International Airport (Johannesburg, South Africa). The airport handles approximately 14 million passengers annually (Airport Council International, 2016). Looking to the future, the airport plans to create the 'airport city concept' (Cairo Airport Authority, 2017), aimed at creating a great customer experience. Siebert and Kasarda (2008) exemplified the airport city concept as the transformation of airports into luxurious shopping malls and artistic and recreational venues. Brand name shops, specialty retail and a variety of restaurants, along with entertainment and cultural attractions, are all among the features that can form a more exhilarating and unique experience for passengers. During the past few years, the airport's quality rating declined from the $82^{\text {nd }}$ position in 2011 to the $100^{\text {th }}$ position in 2012. Since then, it was unable to regain its position among the top 100 airports in the world in terms of customer quality review ratings (Skytrax, 2017). 
Table 2: Top Middle Eastern airports according to customer quality ratings, 2017

\begin{tabular}{|c|c|}
\hline Ranking & Airport \\
\hline $\mathbf{1}$ & Doha Hamad \\
\hline $\mathbf{2}$ & Dubai \\
\hline $\mathbf{3}$ & Abu Dhabi \\
\hline $\mathbf{4}$ & Bahrain \\
\hline $\mathbf{5}$ & Medina \\
\hline $\mathbf{6}$ & Muscat \\
\hline $\mathbf{7}$ & Riyadh \\
\hline $\mathbf{8}$ & Dubai World Central \\
\hline $\mathbf{9}$ & Dammam \\
\hline $\mathbf{1 0}$ & Tel Aviv \\
\hline
\end{tabular}

Source: Skytrax (2017)

The previous facts indicate that CIA needs to provide a better passenger experience in order to enhance its positions among high quality airports in the Middle East.

\section{THE AIRPORT MARKETING THEORY}

Until the 1980s, airports were relatively passive towards their reliance upon marketing. Practitioners were considering airports as monopolistic establishments and did not influence passengers' decisions in target markets. During the past few decades, this viewpoint has changed dramatically. The growing rivalry in the air transport industry made many airport services/products subject to competition, and hence dependent upon marketing to influence consumer decisions. Today, airports have embraced a full-range of contemporary marketing techniques (e.g. relationship marketing-e-marketing-social media marketing) in order to survive. It is important to note that airports are categorized as providers of a service rather than goods. Therefore, it is evident that airports rely on service marketing implications due to its nature and characteristics (Halpern and Graham, 2013). In the following table, various airport service marketing implications are introduced. As mentioned above, airports are now heavily relying on consumer-oriented marketing to survive the ongoing fierce competition. The creation of a unique customer experience is fundamental for marketing contemporary airport services. 
Table 3: The implications of airport service marketing

\begin{tabular}{|c|l|}
\hline Service characteristic & \multicolumn{1}{|c|}{ Airport marketing implications } \\
\hline Inseparability & $\begin{array}{l}\text { Airports must maintain strong relationships } \\
\text { between all service providers and end-users } \\
\text { with an aim to deliver a proper service } \\
\text { outcome. }\end{array}$ \\
\hline No transfer of ownership & $\begin{array}{l}\text { The need to instill brand identity and } \\
\text { encourage loyalty. }\end{array}$ \\
\hline Intangibility & $\begin{array}{l}\text { Airports must create empirical evidence of } \\
\text { their service quality features. }\end{array}$ \\
\hline Heterogeneous & $\begin{array}{l}\text { Investment is needed in quality control to } \\
\text { keep up a high standard service in a variety } \\
\text { of markets. }\end{array}$ \\
\hline Perishability & $\begin{array}{l}\text { Market forecasts are vital for airports as well } \\
\text { as their use of various marketing mix } \\
\text { elements to cope with changes in supply and } \\
\text { demand. }\end{array}$ \\
\hline
\end{tabular}

Source: Modified from Halpern and Graham (2013)

\section{THE CONCEPT OF CUSTOMER EXPERIENCE MANAGEMENT (CEM)}

Today, managers seek to broaden their perspective towards customer's interaction with organizations with the aim to form a more holistic view of the whole journey. Relying heavily on 'touch points' - the various critical moments when customers interact with the organization and its services during the purchase process and after its completion - is now considered as a narrow perspective that diverts the management's attention from seeing the big picture.

The solution to broken service delivery is not solely related to 'touch point' management; the identification of end-to-end customer journeys is even more important. Finding how the organization is performing in each journey and making necessary transformations to the processes with an aim to redesign and support these journeys is fundamental (Rawson, Duncan and Jones, 2013).

The customer experience (CX) can be defined as: "an experience that originates from a set of interactions between a customer and a product, a company, or part of its organization, which will provoke a reaction. This experience strictly personal and implies the customer's involvement at different levels (rational, emotional, sensorial, physical and spiritual) (Gentile, Spiller and Noci, 2007, p.397). 
Chakravorti (2011) highlighted the importance of the relationship between the concept of customer experience management, knowledge management and organizational culture change. Instilling the knowledge base needs across the organization will surely enable knowledge management to attain a high level of organizational learning and hence the creation of added value offerings to the customer experience.

Mukerjee (2012) created a framework that describes the holistic approach towards customer experience management. The framework is presented in Table 4.

Table 4. The framework of CX management

\begin{tabular}{|c|l|}
\hline Impacts of CX & \multicolumn{1}{c|}{ Issues } \\
\hline Senses & $\begin{array}{l}\text { Visual impact } \\
\text { Auditory and olfactory impact }\end{array}$ \\
\hline Processes & $\begin{array}{l}\text { Interaction, method } \\
\text { Customer view } \\
\text { Tools used to enable processes }\end{array}$ \\
\hline Communication & $\begin{array}{l}\text { Communication formats } \\
\text { Consistency across multiple channels }\end{array}$ \\
\hline Professionalism & $\begin{array}{l}\text { Excellence in product / service performance } \\
\text { Contemporary practices }\end{array}$ \\
\hline \multirow{2}{*}{ Relationship } & $\begin{array}{l}\text { Special treatment offered to loyal customers } \\
\text { Experience throughout the product / service } \\
\text { lifecycle }\end{array}$ \\
\hline
\end{tabular}

Source: Mukerjee (2012)

The hierarchy of the above mentioned elements is demonstrated in Figure 1.

Enhancing the passenger experience includes: 1. Identifying key journey elements, 2. Understanding current performance, 3. Redesigning the experience (Rawson, Duncan and Jones, 2013). McKinsey (2016) also defined three different perspectives to create and sustain distinctive customer experiences:

\section{A-Customer's viewpoint}

-Identify customer experience

-Align the processes and end product with customer requirements and expectations.

-Determine key drivers for improvements from customers' perspective. 
Figure 1: The passenger experience management pyramid

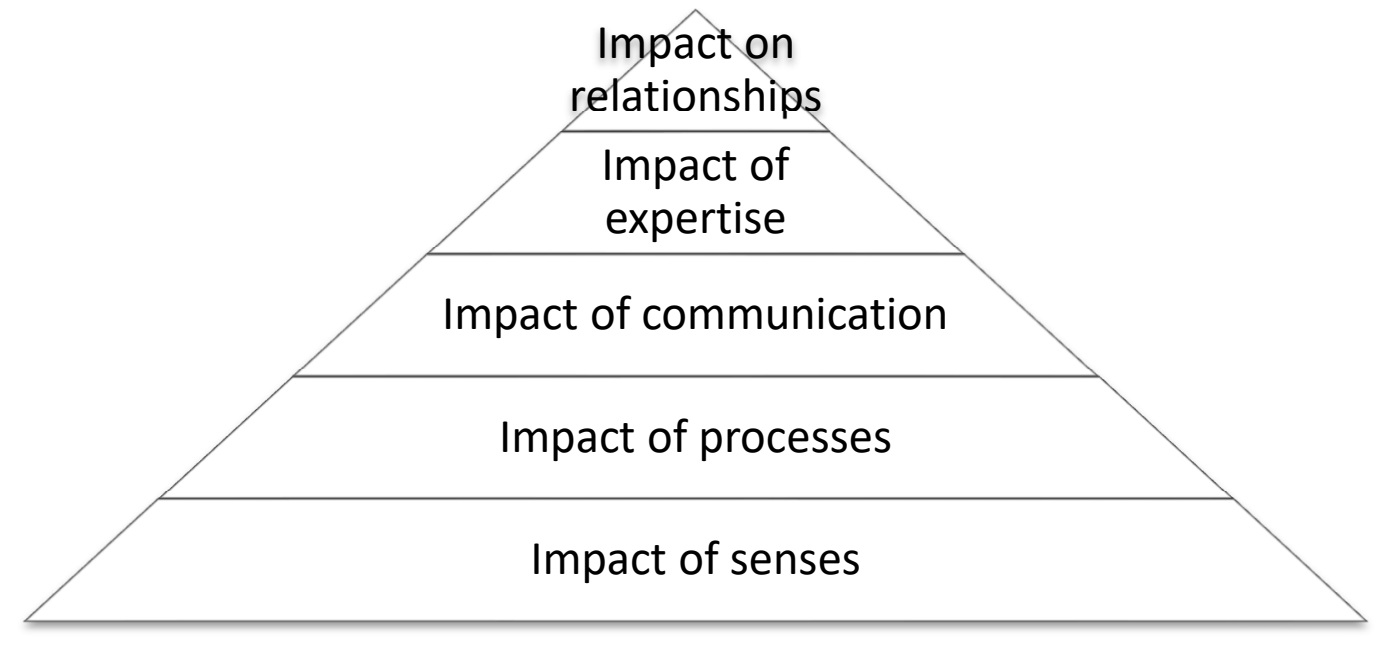

Source: Mukerjee (2012)

\section{B-Journey assessment}

-Recognize current work flow.

-Identify weak points in process flows and key interfaces.

-Analyze networking among various parts of the organization.

\section{C-Leadership alignment}

-Conduct meetings with senior managers in order to understand the current performance.

-Organize workshops to create a joint aspiration on consumer orientation.

-Recognize the mind-sets and behavior across various levels on customer orientation.

\section{THE AIRPORT PASSENGER EXPERIENCE}

Managers consider the airport industry as a very diverse business field. Airports are characterized with a high degree of differentiation between service quality levels, diverse forms of ownership and management structures. Airport characteristics are also influenced by various environmental factors related to its geographical location (Oum, Yu and Fu, 2003). The evaluation of airport operational efficiency is complicated due to previously mentioned differences. Passenger satisfaction has become a key objective in service operations because of the benefits it brings to organizations (Ranaweera and Prabhu, 2003). Lubbe and Zambellis (2011) confirmed that the main measure of airport operation efficiency is passengers' 
opinions; therefore it is highly important to analyze passengers' expectations towards airport services.

Nowadays, travelers search for 'authentic experiences' as a temporary escape from daily life routine. In a world of chaos and irregularity, the terminal can be seen as a worthy and intriguing refuge of elegance and logic. Improving the customer experience relies upon the adoption of 'humanistic approaches towards the customer rather than regarding people as information processors and rational decision makers (Losekoot, 2015).

The airport customer experience can be defined as: "the net impression of all the experiences a customer has in an airport, as judged by customers based on their individual standards, expectations and perceptions". (Airport Cooperative Research Program, 2015, p.4). The airport customer experience management can be described as a systematic approach to manage the net impression (emotional and rational) produced by the airport experience. It includes the strategies and processes employed by airport management to plan, engineer, implement and sustain satisfying customer experiences from the customer's perspective across the entire service delivery chain. The customer touch points in airports encompass all the interactions that a passenger has during his journey. They can be categorized into: physical (the airport elements that are experienced through any of the five human senses) procedural (interaction with the airport system)-human (interpersonal with the airport staff)sublimal (airport ambiance /atmosphere that evoke passengers' feelings throughout various levels of consciousness)

In order to maintain a positive sense in the customer's impression of an experience, the airport management should also pay attention to various moments of truth. The moments of truth represent significant touch points than can disrupt the management's trials to create a positive customer experience. Superior handling of moments of truth can differentiate airports that seek to attain a high level of customer satisfaction. Moments of truth can include the following negative outcomes: lost luggage, missed flights and rude airport employees. (Airport Cooperative Research Program, 2015, p.4).

The following figure illustrates the various domains / phases of the passenger airport experience. 
Figure 2: Airport domains of the overall passenger experience
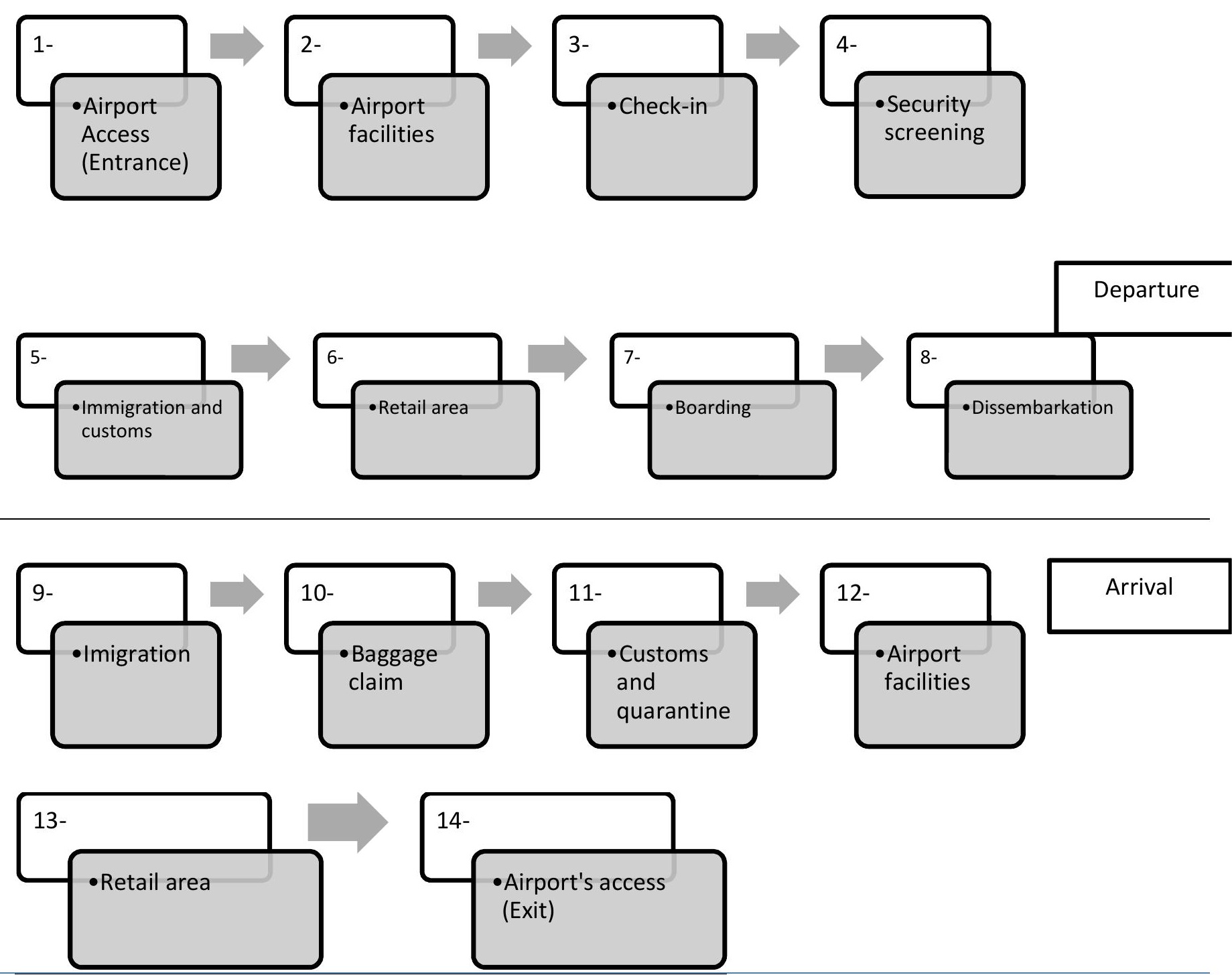

Source: Modified from Wiredja, Popvic and Blackler (2015)

Hess and Polak (2005) found that many non-price characteristics have a strong impact on the passenger's choice probabilities (e.g. airport access time- airport delay-early arrival times).

Passengers' expectations of the airport's service quality are mainly formed by three dimensions: 1- Function (effectiveness and efficiency) 2-Interaction (expectations regarding the airport staff) 3-Diversion (distracting passengers from possible airport boredom) (Fodness and Murray, 2007).

Bandeira and Correia (2012) confirmed that passengers' profiles influence their impressions towards their airport experience. They ascertained that age, reason for traveling, frequency 
of air travel influence passengers' expectations regarding the check-in and the departure lounges area. These findings confirm the necessity of mapping the profiles of passengers in order to properly evaluate their customer experience (CX) and further more contribute to the development of the airport services and ambience.

It is crucial for the airport management to understand and embrace what drives customer satisfaction and perception. In the following table, a number airport service elements and amenities that can influence airport passenger experience are demonstrated.

Table 5: Sample elements of the airport customer experience (CX)

\begin{tabular}{|l|l|}
\hline Sense of place: & -Airport signage \\
\hline -Architecture & -Queue management \\
-Live music & -Waiting distances \\
-Local cuisine & -Loyalty and reward programs \\
-Local events & -Parking \\
-Art and museum exhibitions & -Ground transportation \\
-Local sightseeing tours & -Check-in/ticketing/baggage drop \\
Corporate concessions: & -Security a \\
\hline -Airport pay lounges & -Flight Information and passenger \\
-Ordering through touch-screen devices & information \\
-Healthy foods & -Hold rooms (seating areas) \\
-Local foods & -Domestic arrivals and baggage claim \\
-Internet services: Free Wi-Fi & -Arrival concessions \\
Amenities & -Efficient customer service \\
\hline -Location rooms & -International arrivals facilities \\
-Restrooms: restroom attendants / restroom & Other innovations: \\
for pets (pets relief areas) & -Yoga rooms \\
& -Hydration stations \\
\hline
\end{tabular}

Source: Compiled from ACRP (2016)

It's important to note that intangible features of the airport also have a noticeable influence on passengers. Ariffin and Yahaya (2013) confirmed that there is a strong relationship between the airport image and passenger delight. An airport design with national characteristics, for example, can have a positive impact on passengers' impressions. Bogicevic (2014) stated that airport design and appearance play a significant role in the quality of the passenger experience throughout his journey. 'Servicescape' is a term used to embody the environment where the service is delivered takes place. The servicescape consists of the groups of physical evidence factors: 1 . Ambient conditions (e.g. air quality- temperaturemusic-noise-aroma); 2. Spatial layout and functionality (e.g. building layout-furnitureequipment); 3. Signs, symbols and artifacts (e.g. signage-décor-artifacts). Other servicescape 
elements include: landscape-employee dress-virtual landscape. It is evident that servicescape features can play an essential part in creating a likeable environment for passengers during their journey throughout the airport.

It is worth mentioning that Information Communication Technologies (ICT) also play a significant role in the contemporary airport passenger experience. ICT innovations (e.g. biometric technologies, Near Field Communication, Big data-smartphones) can gradually revolutionize the airport passenger experience. The Lisbon Portela Airport, for example, was able to reduce its boarding time by $80-90 \%$ (Kalakou, Psaraki and Moura, 2015).

On the other hand, there social-related factors that influence the passenger experience along with the before mentioned automated features. Minton (2008) investigated the check-in experience and concluded that many passengers preferred the human interaction over selfservice technologies due to social-related factors. Although automation can significantly shorten the queuing time, a proportion of passengers are reluctant to use self-service technologies because of their fear of embarrassment.

These facts confirm that passengers differ in terms of technological literacy and tendency to use technologies, and hence, designing a satisfactory airport experience needs in-depth analysis of diverse passenger needs and wants in various markets. Losekoot (2015) summarized the key factors influencing the airport experience form the view point of passengers: 1 . the physical environment and airport facilities; 2 . the processes of the airport and those delivering the services, 3. the people at the airport (both staff and airport passengers), 4 . the sense of place of all above mentioned factors.

The following figure demonstrates the various impressions of passengers towards different levels of airport experiences. All airport managers should seek to improve the airport journey with an aim to create a sense of place for all passengers where there is excitement / anticipation for every element they encounter.

In conclusion, airports are now considered as an industry that operates in a unique and ever changing physical, financial and regulatory environment. In order to develop an airport's overall framework of strategic customer management system, managers will need to determine a number of key performance indicators (KPIs). The trend towards mobilizing and exploiting the airport's intangible or invisible assets has become far more crucial than investing and managing physical / tangible assets. Customer relationship management (CRM) has been identified as an intangible asset that will help the airport retain the loyalty of existing 
customers and furthermore enable the new customer segments and targeted markets to be served effectively and efficiently (Kamarudin, 2015).

Figure 3: The airport experience model

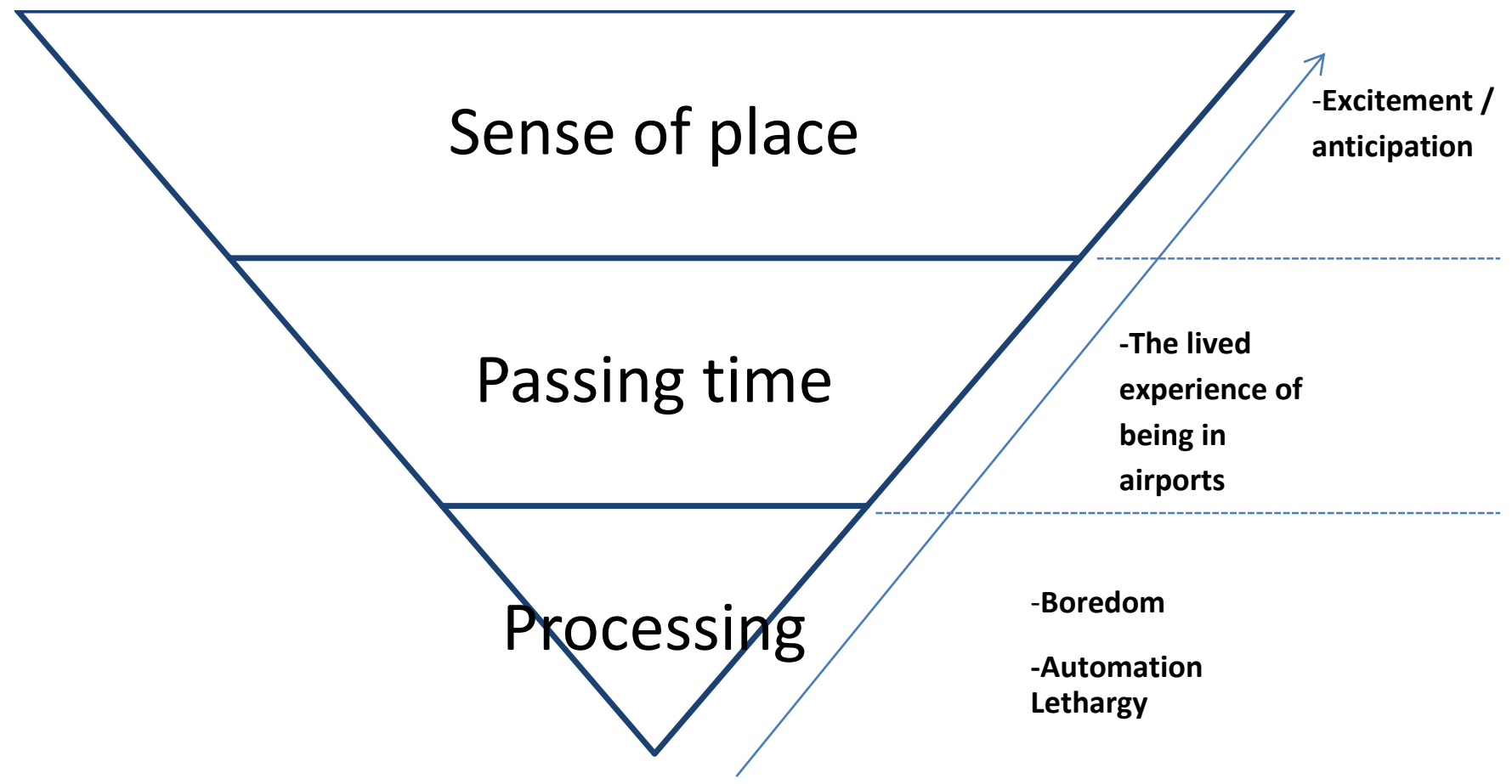

Source: Losekoot (2015)

\section{METHODOLOGY}

\subsection{Research Objectives}

The research seeks to identify the elements of the airport experience that delight passengers during their journey beyond the limits of 'touch points' and 'moment of truth' concepts. The passenger survey was conducted at Cairo International Airport (CIA) during the months of April, May and June, 2017. The survey questionnaire was self-administered randomly to passengers (in terminals 1,2 and 3 ) in the form of a formal one-on-one interviews that aim to determine respondents' impressions regarding their airport experience with CIA, and to further find out their perspective towards the various elements they encountered during their journey. The respondents were also asked an open-ended question that explores the elements of the airport experience that need further improvements. The research identified key areas that affect passengers' journey which later formed the ways to enhance the overall customer experience at CIA. The research objectives are summarized in the research model shown in figure 4. 
Figure 4: Research model

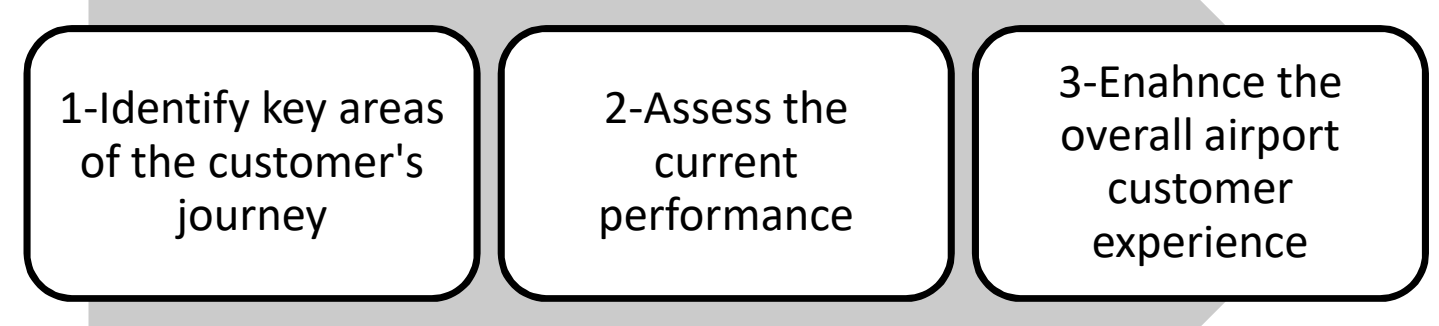

The research aims to identify key areas of the passenger journey (according to their importance), recognize various defects of the airport experience, and finally suggest ways of enhancing the overall passenger journey. Furthermore, the construction of the passenger experience survey is demonstrated in table 6.

Table 6: Design structure of the passenger survey

\begin{tabular}{|l|c|c|}
\hline \multicolumn{1}{|c|}{ Airport experience dimension } & $\begin{array}{c}\text { Element } \\
\text { Code }\end{array}$ & Element \\
\hline \multirow{4}{*}{ Airport access procedures (AA) } & AA1 & Check-in \\
\cline { 2 - 3 } & AA2 & Immigration and customs \\
\cline { 2 - 3 } & AA3 & Boarding procedures \\
\hline \multirow{4}{*}{ Airport services and facilities (AS) } & SF1 & Flight and passenger information \\
\cline { 2 - 3 } & SF2 & Retail shops \\
\cline { 2 - 3 } & SF3 & Dining areas \\
\cline { 2 - 3 } & SF4 & Wi-Fi connectivity \\
\cline { 2 - 3 } & SF5 & Passenger lounge \\
\cline { 2 - 3 } & SF6 & Terminal seating \\
\cline { 2 - 3 } & SF7 & Restrooms \\
\cline { 2 - 3 } & SF8 & Luggage Claim \\
\cline { 2 - 3 } & SF9 & Ground transportation \\
\hline \multirow{2}{*}{ Airport Personnel (AP) } & AP1 & Airport customer care \\
\cline { 2 - 3 } & AP2 & Airport staff efficiency \\
\hline \multirow{4}{*}{ Airport environment (AE) } & AA1 & Airport design \\
\cline { 2 - 3 } & AE2 & Terminal cleanliness \\
\cline { 2 - 3 } & AE3 & Airport amenities \\
\cline { 2 - 3 } & AE4 & Airport ambience \\
\hline
\end{tabular}


Means were calculated to find out the most important areas of the airport experience that were mostly mentioned by respondents during the formal interviews. A content analysis was undertaken to the open-ended section of the survey with an aim to give passengers the chance to express their impressions, sentiments and aspirations towards their experience with CIA. 'Aquad v.7' (a renowned computer assisted quantitative data analysis software) was used to perform a quantitative content analysis of all gathered open-ended replies in order to classify passenger impressions according to the predefined airport experience categories. Respondents' consensus towards various elements is reached at the end of the content analysis. Finally, the research suggested a number of recommendations that will help enhance the overall airport passenger experience of CIA.

\subsection{Sampling}

Due to the large population size $(\mathrm{N}=14,969,000)$, a table of sample sizes was used at a confidence level of $95 \%$ and a reliability level of \pm 5 , which is appropriate for this type of research (Ritchie and Goeldner, 1994). The maximum sample size was chosen $(n=384)$ and 16 additional questionnaires were added to compensate for non-responses. The final sample was size ( $n$ ) was determined to be 400 questionnaires. The survey acquired 211 valid responses which accounts for $52 \%$ of the total sample. It is acceptable response rate for these types of surveys (Ritchie and Goeldner, 1994).

Table 7: Value ranges and scales of the demographic variables

\begin{tabular}{|c|c|}
\hline Demographic Variables & Value ranges / scales \\
\hline Gender & Male-Female \\
\hline Age category & $\begin{array}{cc}\text { Less than } 18 / & 18-24 / 25-34 / 35-44 / 45- \\
& 54 / 55+\end{array}$ \\
\hline \multirow[t]{5}{*}{ Education } & High school \\
\hline & Bachelors \\
\hline & Master \\
\hline & $\mathrm{PhD}$ \\
\hline & Other \\
\hline Frequency of air travel / year (experience) & $1-3$ / 4-6 / 7-11/ 12+ \\
\hline \multirow[t]{6}{*}{ Occupation fields } & Education \\
\hline & Business and finance \\
\hline & Management / Administrative \\
\hline & Architecture and engineering \\
\hline & Laborer \\
\hline & Unemployed \\
\hline
\end{tabular}




\subsection{Research Hypotheses}

In order to test the relationship between the socio-demographic profiles of respondents, the passengers' ratings of various airport elements and the overall impression of respondents towards the overall airport experience, five hypotheses were formulated. The validity of the following five hypotheses was tested using ANOVA and multiple regression analysis (The SPSS v.22.0 was used to elicit various results).

H0- Passengers' impressions towards their overall experience with Cairo International Airport will not differ according to their socio-demographic characteristics (gender-age-educationoccupation-frequency of air travel).

The alternative hypothesis is: H1- Passengers' impressions towards their overall experience with Cairo International Airport will differ according to their socio-demographic characteristics (gender-age-education-occupation-frequency of air travel).

The single factor ANOVA (analysis of variance) test is used to determine whether any of the differences between the means are statistically significant by comparing the $p$-value to the significance level in order to assess the null hypothesis (the null hypothesis states that the means are all equal). The research significance level is $0.05(p=0.05)$.

H02- There is a positive relationship between passengers' perception of airport access procedures and the overall impression of the airport experience.

H03- There is a positive relationship between passengers' perception of airport services and facilities and the overall impression of the airport experience.

H04- There is a positive relationship between passengers' perception of the airport environment and the overall impression of the airport experience

H05- There is a positive relationship between passengers' perception of airport personnel and the overall impression of the airport experience

\section{RESULTS AND DISCUSSION}

\subsection{Reliability Test}

Reliability is defined as the tendency toward consistency found in repeated measurements of the same phenomenon. Therefore, a reliability test was conducted to assess the quality of the data and Cronbach's alpha was computed to measure the internal consistency of the 
responses to all items of the survey. The reliability test results $(a=0.98)$ shows that items exhibit a highly acceptable level of reliability $(a>0.90)$.

\subsection{Descriptive Statistics}

As shown in figures 5 and 6 respectively, $96.2 \%$ of respondents were flying on international routes and $94.3 \%$ of respondents were traveling for leisure purposes. The majoritiy of respondents were males ( $83.8 \%$ ) and were in the category of $25-34$ years old (54.5\%). They are followed by the category of $35-44$ years old (20.2\%). $77.8 \%$ of respondents travel from 1 to 3 times per year. The majority of respondents have at least a Bachelor's degree (57.6\%). The majority of respondents (50\%) work in management-related professions.

Figure 5: Flight route type

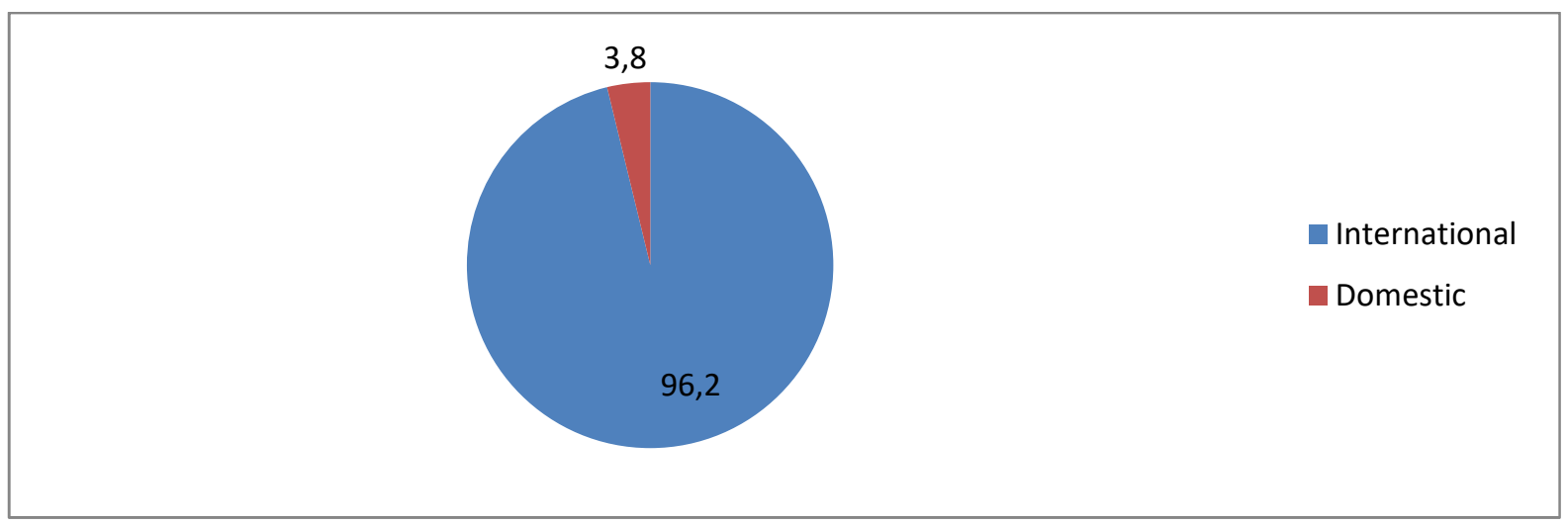

Figure 6: Trip purpose

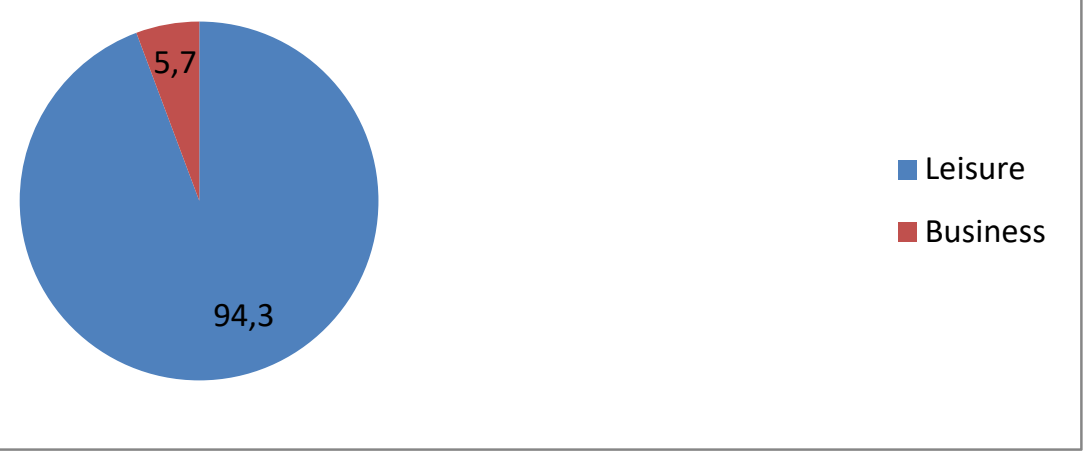


Table 8: Socio-demographic characteristics of respondents

\begin{tabular}{|c|c|c|}
\hline Attribute & Scale & $(\%)$ \\
\hline \multirow{2}{*}{ Gender } & Male & 83.8 \\
\hline & Female & 16.2 \\
\hline \multirow[t]{6}{*}{ Age } & Less than 18 & 2 \\
\hline & $18-24$ & 5.1 \\
\hline & $25-34$ & 54.5 \\
\hline & $35-44$ & 20.2 \\
\hline & $45-54$ & 12.1 \\
\hline & $55+$ & 6.1 \\
\hline \multirow[t]{4}{*}{ Frequency of air travel } & $1-3$ & 77.8 \\
\hline & $4-6$ & 13.1 \\
\hline & $7-11$ & 3 \\
\hline & $12+$ & 6.1 \\
\hline \multirow[t]{5}{*}{ Education } & High school & 2 \\
\hline & Bachelors & 57.6 \\
\hline & Master & 19.2 \\
\hline & PhD & 20.2 \\
\hline & Other & 1 \\
\hline \multirow[t]{6}{*}{ Occupation fields } & Education & 40 \\
\hline & Business and finance & 2 \\
\hline & Management / Administrative & 50 \\
\hline & Architecture and engineering & 4 \\
\hline & Laborer & 2 \\
\hline & Unemployed & 2 \\
\hline
\end{tabular}

Figure 7: Passengers' Impressions of the Overall Airport Experience

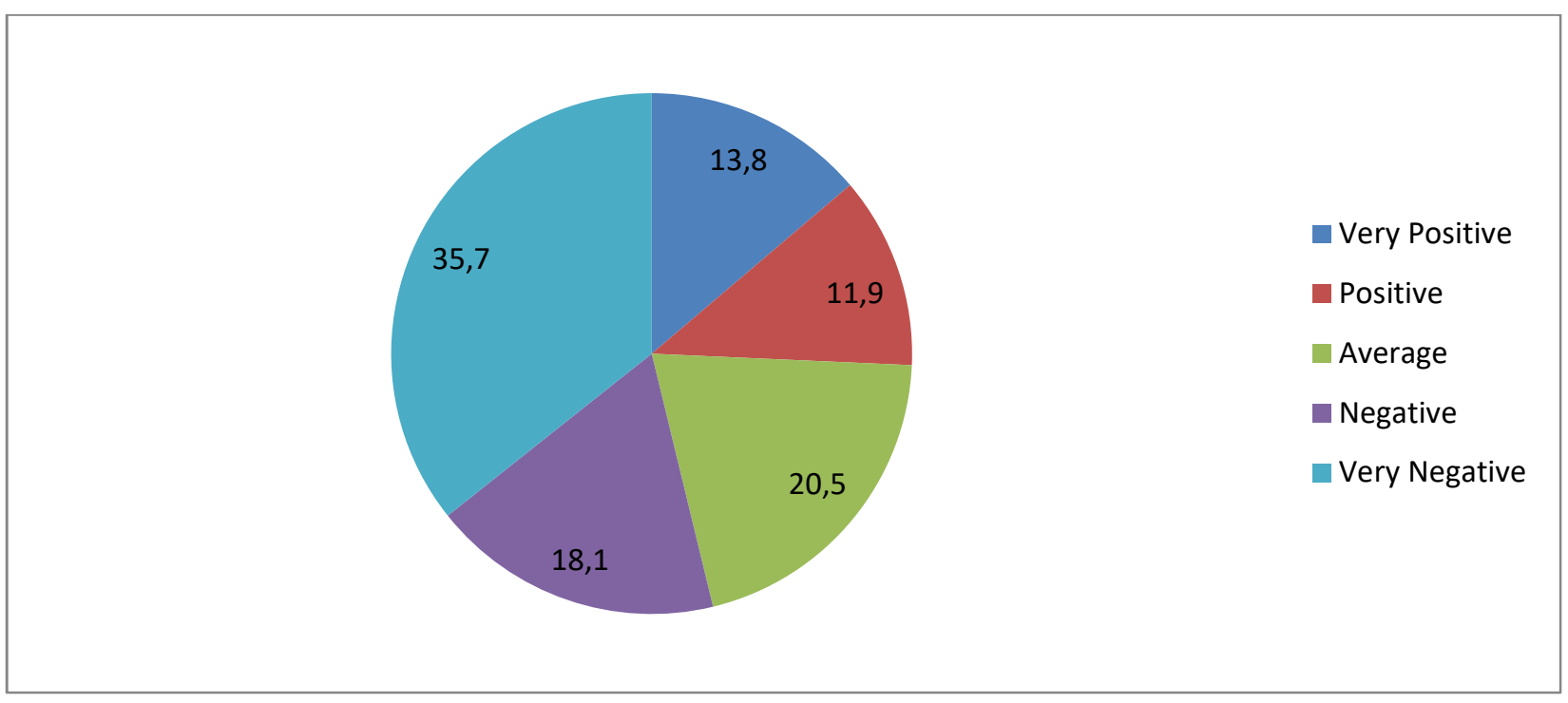


The results in figure 7 indicate that the overall airport experience is below average according to passengers' ratings. The majority of responses were ranging from negative to very negative. The mean score (2.50) of the overall impression of the airport experience confirms this fact in the following table. It's clear from the previous results in table 9 that passengers' ratings of airport experience elements of CIA are below average.

Table 9: Mean and standard deviation of airport experience elements

\begin{tabular}{|l|c|c|}
\hline Airport Experience Elements $(n=211)$ & Mean & STDV \\
\hline Terminal Cleanliness & 2.70 & 1.53 \\
\hline Airport design & 2.57 & 1.48 \\
\hline Airport amenities & 2.56 & 1.36 \\
\hline Luggage claim & 2.55 & 1.41 \\
\hline Retail shops & 2.54 & 1.48 \\
\hline Check-in & 2.53 & 1.46 \\
\hline Passenger lounge & 2.52 & 1.44 \\
\hline Wi-Fi & 2.51 & 1.42 \\
\hline Boarding & 2.5 & 1.38 \\
\hline Restroom & 2.48 & 1.43 \\
\hline Flight and passenger information & 2.47 & 1.39 \\
\hline Terminal seating & 2.46 & 1.45 \\
\hline Dining areas & 2.45 & 1.47 \\
\hline Immigration and customs & 2.44 & 1.42 \\
\hline Airport staff efficiency & 2.42 & 1.49 \\
\hline Ground transportation & 2.41 & 1.42 \\
\hline Airport ambiance & 2.38 & 1.53 \\
\hline Airport customer care & 2.30 & 1.55 \\
\hline Overall impression of the airport experience & 2.50 & 1.42 \\
\hline
\end{tabular}

Notes: $1-$ STDV $=$ Standard deviation

2-Passenger rating scale ( $1=$ Excellent, $2=$ Good, $3=$ Average, $4=$ Poor, $5=$ Very poor)

\subsection{Key Areas of the Customer Journey}

Responses of passengers' perception of importance of various airport experience elements are demonstrated the following figure. 
Figure 8: Passengers' expectations of key elements of the airport experience (frequencies)

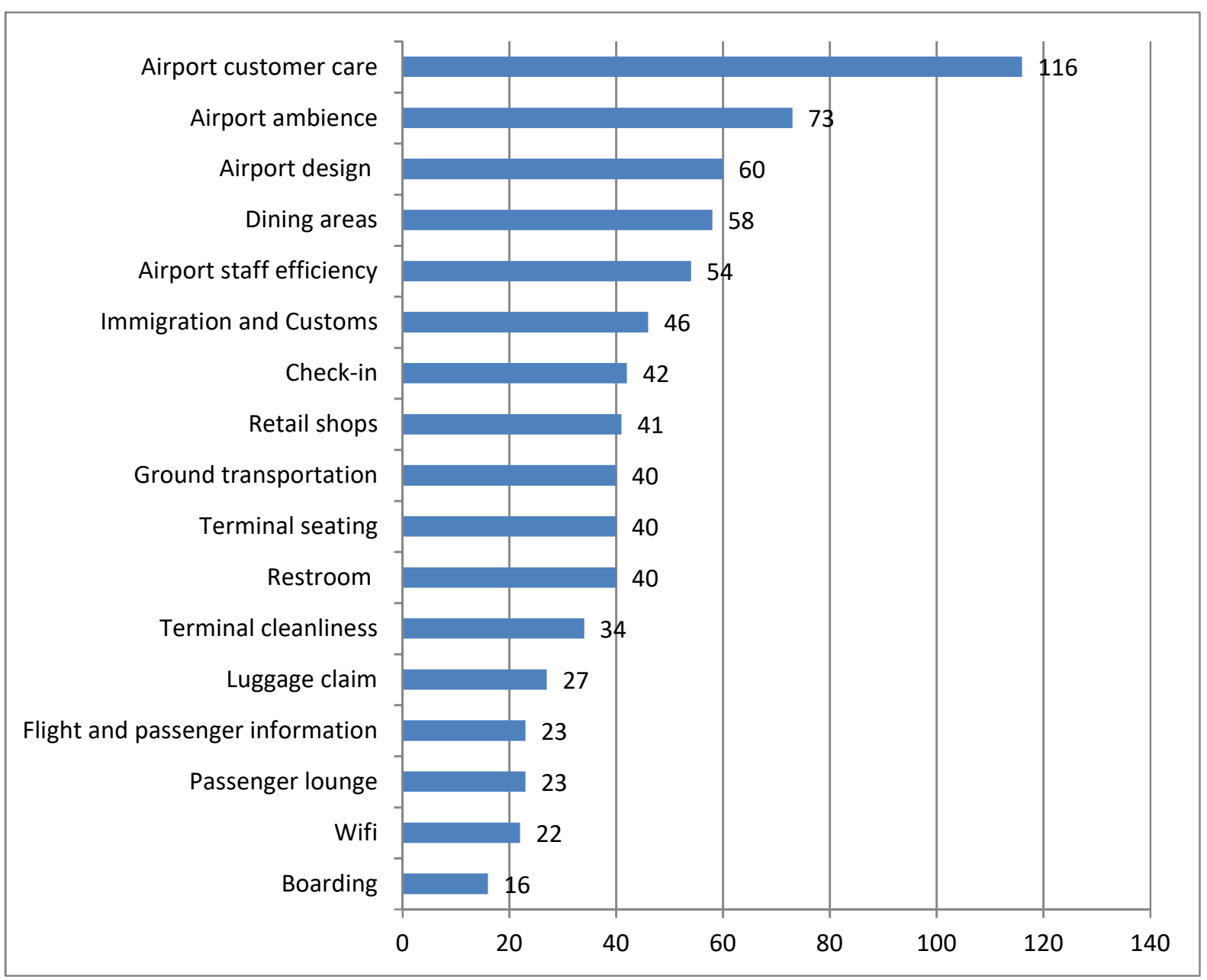

\subsection{Hypotheses Testing}

As shown in table 10, the analysis of variance results showed that the effect of sociodemographic characteristics on respondents' impression of the overall airport experience was significant, gender $[F(1,418)=4.38, p=0.036,(p<0.05)]$; age $[F(5,1254)=2.25, p=0.046$ $(p<0.05)]$; frequency of air travel $[F(3,836)=2.74, p=0.042, \quad(p<0.05)]$; education $[F(4,1045)=2.80, p=0.024 \quad(p<0.05)]$ and occupation $[F(5,1254)=3.043, p=0.009$, $(p<0.01)]$. It's therefore confirmed from the ANOVA test results that the null hypothesis $-\mathrm{HO}$ is rejected. The alternative hypothesis is therefore supported.

Hypothesis 1: Passengers' impressions towards their overall experience with Cairo International Airport will differ according to their socio-demographic characteristics (genderage-frequency of air travel-education-occupation). 
Table 10: ANOVA test results between respondents' impressions of the overall airport experience and socio-demographic variables

\begin{tabular}{|c|c|c|c|c|c|c|}
\hline Attributes & $\begin{array}{l}\text { Source of } \\
\text { Variation }\end{array}$ & ss & D.F. & MS & $\boldsymbol{F}$ & Significance \\
\hline \multirow{3}{*}{ Gender } & Between Groups & 10.371 & 1 & 10.371 & \multirow{3}{*}{4.388} & \multirow{3}{*}{$0.036^{*}$} \\
\hline & Within Groups & 987.857 & 418 & \multirow{2}{*}{2.363} & & \\
\hline & Total & 998.228 & 419 & & & \\
\hline \multirow{3}{*}{ Age } & Between Groups & 25.368 & 5 & 5.073 & \multirow{3}{*}{2.258} & \multirow{3}{*}{$0.046^{*}$} \\
\hline & Within Groups & 2817.485 & 1254 & \multirow{2}{*}{2.246} & & \\
\hline & Total & 2842.853 & 1259 & & & \\
\hline \multirow{3}{*}{$\begin{array}{c}\text { Frequency } \\
\text { of air } \\
\text { travel }\end{array}$} & Between Groups & 18.298 & 3 & 6.099 & \multirow{3}{*}{2.741} & \multirow{3}{*}{$0.042^{*}$} \\
\hline & Within Groups & 1859.690 & 836 & \multirow{2}{*}{2.224} & & \\
\hline & Total & 1877.989 & 839 & & & \\
\hline \multirow{3}{*}{ Education } & Between Groups & 25.260 & 4 & 6.315 & \multirow{3}{*}{2.803} & \multirow{3}{*}{$0.024 *$} \\
\hline & Within Groups & 2353.790 & 1045 & \multirow{2}{*}{2.252} & & \\
\hline & Total & 2379.051 & 1049 & & & \\
\hline \multirow{3}{*}{$\begin{array}{l}\text { Occupation } \\
\text { fields }\end{array}$} & Between Groups & 34.711 & 5 & 6.942 & \multirow{3}{*}{3.043} & \multirow{3}{*}{$0.009 * *$} \\
\hline & Within Groups & 2860.285 & 1254 & \multirow{2}{*}{2.280} & & \\
\hline & Total & 2894.996 & 1259 & & & \\
\hline
\end{tabular}

Note: $* \mathrm{p}<0.05 ; * * \mathrm{p}<0.01 ; * * * \mathrm{p}<0.001$

A multiple regression analysis was also used to test the effect of all airport dimensions (independent variables) on respondents' overall impression towards the airport experience (dependent variable). The following table shows the results of the multiple regression analysis.

Table 11: Multiple regression analysis results

\begin{tabular}{|c|c|c|c|c|}
\hline Element & Beta & t-test & P value & Remark \\
\hline Airport services and facilities & $0.456^{* * *}$ & 5.919 & 0.000 & Supported \\
\hline Airport access procedures & $0.235^{* * *}$ & 3.783 & 0.000 & Supported \\
\hline Airport environment & $0.182^{* *}$ & 3.367 & 0.001 & Supported \\
\hline Airport personnel & $0.155^{* * *}$ & 4.233 & 0.000 & Supported \\
\hline
\end{tabular}

Note: $* p<0.05 ; * * p<0.01 ; * * * p<0.001$

\section{Hypothesis 2: Supported}

The results confirm that the services and facilities have a positive significant influence on respondents' overall impression with airport experience elements $(\beta=0.456, p<0.001 ; t-$ value $=5.919)$. 


\section{Hypothesis 3: Supported}

The results confirm that the airport access procedures have a positive significant influence on respondents' overall impression with airport experience elements $(\beta=0.235, p<0.001$; $t$ value=3.783).

\section{Hypothesis 4: Supported}

The results confirm that the airport environment have a positive significant influence on respondents' overall impression with airport experience elements $(\beta=0.182, p<0.01$; tvalue=3.367)

\section{Hypothesis 5: Supported}

The results confirm that the airport personnel have a positive significant influence on respondents' overall impression with airport experience elements $(\beta=0.155, p<0.001$; tvalue $=4.233$ ).

In conclusion, it is confirmed the airport services and facilities dimension has the most significant effect on respondents' overall airport experience elements $(\beta=0.456)$ followed by airport access procedures $(\beta=0.235)$, the airport environment $(\beta=0.182)$ and finally the airport personnel $(\beta=0.155)$.

\subsection{Airport Experience Ratings and Perception of Importance}

The following scatter diagram (Figure 9) shows that the level of the airport experience is below average with respect to the importance of various airport elements. Results confirm that the airport is not delighting passengers on the most important drivers of satisfaction. The most significant defect is apparent in the "Airport customer care" were it is ranked as the most important element of the airport experience and has a below average passenger rating (2.30) (see Table 12). 
Figure 9: Passenger airport experience ratings vs. perception of importance

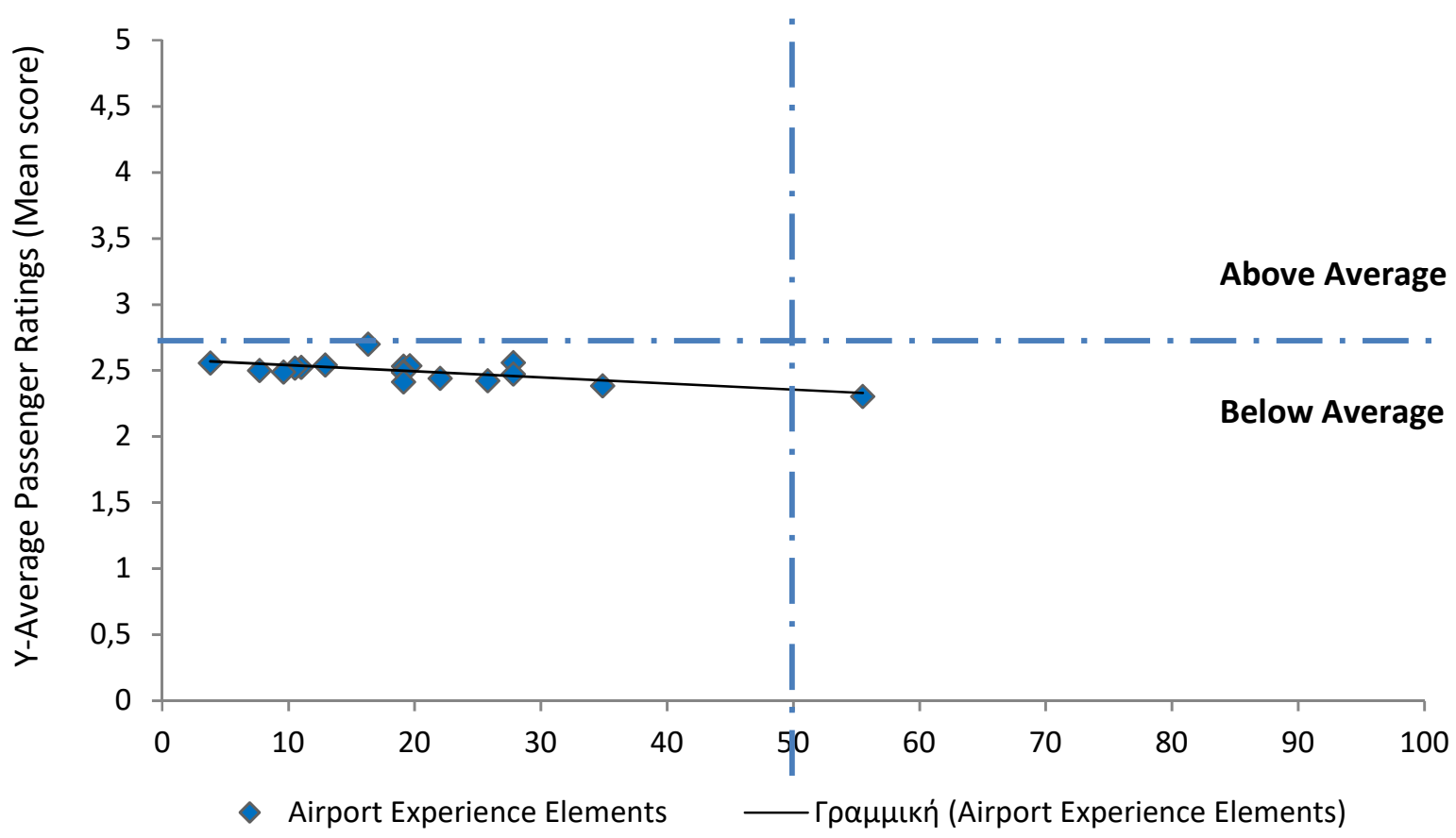

X-Passenger perception of importance (\%)

Note: -Average Passenger ratings ( $1=$ Excellent $-5=$ Very Poor)

Table 12: Top airport experience elements by passenger ratings

\begin{tabular}{|c|c|c|c|c|}
\hline Ranking & Dimension & $\begin{array}{c}\text { Airport Experience } \\
\text { Element }\end{array}$ & $\begin{array}{c}\text { Importance } \\
\mathbf{( \% )}\end{array}$ & $\begin{array}{c}\text { Average } \\
\text { passenger rating } \\
\text { (mean score) }\end{array}$ \\
\hline $\mathbf{1}$ & AP & Airport customer care & 55.5 & 2.30 \\
\hline $\mathbf{2}$ & AE & Airport ambience & 34.9 & 2.38 \\
\hline $\mathbf{3}$ & AE & Airport design & 30 & 2.57 \\
\hline $\mathbf{4}$ & AS & Dining areas & 27.8 & 2.45 \\
\hline $\mathbf{5}$ & AP & Airport staff efficiency & 25.8 & 2.42 \\
\hline
\end{tabular}

Note: $A P=$ Airport personnel $-A E=$ Airport Environment- $A A=$ Airport access procedures- $A S=$ Airport services and facilities

\subsection{Content Analysis Results}

Open-ended questionnaire responses were gathered with an aim to identify the airport experience dimensions in need of further improvements according to passengers' perspectives. The responses were coded after extracting the negative sentiments expressed in each reply. 'Aquad v.7' was used to perform a quantitative content analysis of all gathered 
replies with an aim to categorize all mentioned negative elements according to the predefined airport experience elements. The results are shown in the following diagram (Figure 10).

Figure 10: Dimensions of the airport experience in need of further improvements (frequencies)

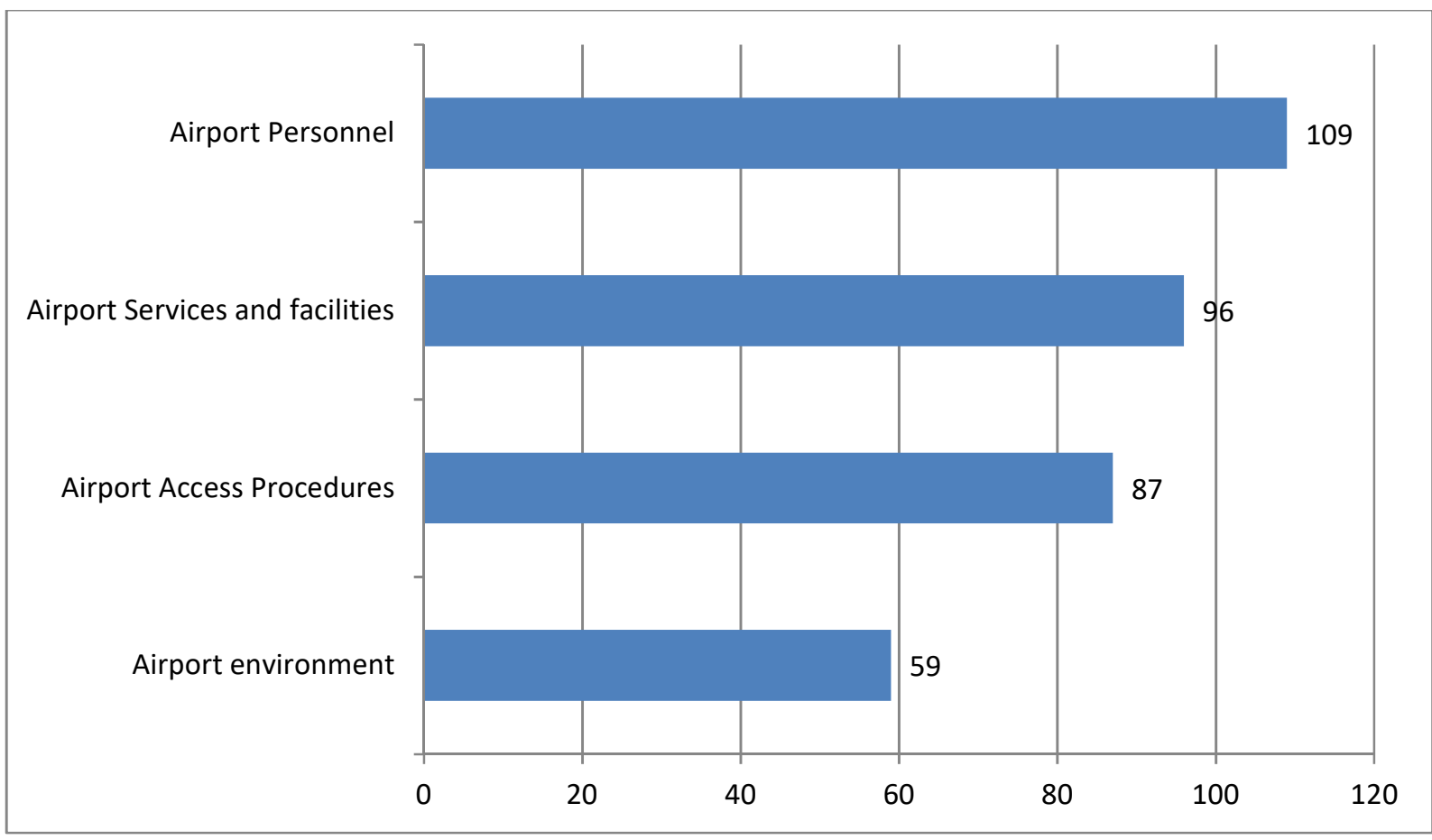

\subsection{Overview of Open-ended Responses}

Most of the responses (64.9\%) were criticizing the airport personnel of CIA. Respondents were mainly complaining about a number of airport workers (hustlers) who try to exploit passengers by offering unneeded services or assistance in many areas of the airport access procedures. The airport customer care is underperforming according to surveyed passengers. Respondents were hoping to find a wider range of multilingual airport staff at the airport to provide them with necessary assistance. Regarding the airport services and facilities $(57.1 \%)$, respondents were mainly complaining about the ground transportation. Airport taxi drivers are scamming passengers by overcharging their fares. Another area in need of further improvement is the dining areas. Passengers need a more diverse dining experience (various types of international cuisines). 
The retail shops were described by the majority as overpriced and offering a moderate array of products. The Wi-Fi connectivity is weak and needs further enhancements. The restrooms are well-maintained, but still workers are continuously trying to exploit passengers in this area. Business lounges are not distinctive by any means, compared to world standards, and need more renovations to meet passenger expectations. The luggage claim is seen as slow and frustrating due to baggage delays. In times of congestion, passengers realize that the airport needs to increase its seating capacity, especially at boarding areas.

The airport access procedures (51.8\%) dimension is related to the queuing time. Respondents think that there are too many security screenings at the airport. The elapsed time of the airport procedures should be minimized according to respondents. As for the airport environment (35.1\%), it is clear that new terminals (T2 and T3) appear ultra-modern and well-designed after recent innovations. However, the overall ambience of the airport is negative. More specifically, respondents describe CIA as chaotic, overcrowded, unorganized and noisy. Airport ground staff needs to make better effort in organizing queue lines and passenger movements through the airport. Respondents see the CIA experience as an average one. More amenities are needed to provide passengers with a more joyful and exciting experience.

\section{CONCLUSIONS}

The research proved that socio-demographic profiles of respondents (gender-age-frequency of air travel-education-occupation fields) have an influence on their overall impression of the airport experience. The research also concluded that the four main dimensions (the airport's services and facilities, access and procedures, environment and personnel) have a positive significant influence on passengers' overall airport experience. The research confirmed that services and facilities are the most significant dimension of the airport experience. Regarding elements of the airport passenger experience, the top five are (in order of importance): airport customer care, airport ambience, airport design, dining areas, and airport staff efficiency (it is important to note that dimensions and elements can vary in importance among different airports and various survey groups). The research confirmed that CIA is not exceling in any of these elements. CIA provides its passengers with a below average customer experience (CX).

Many of the areas in need of further improvement at CIA are linked to the human input. The irregularity of passenger movement in the airport and the problems associated with the 
prolonged queuing times and the hustling workers are all considered managerial issues related to the airport staff performance. It is clear that customer care has become the cornerstone of any differentiation strategy, given the homogeneity of the air transport industry.

The results also assure the importance of the airport ambience and design over many other access and service-related elements. An airport that has an ambiance that compiles positive characteristics (e.g. sense of warmth- excitement-enjoyment) along with a unique design, an array of outstanding services and a caring staff can easily create a highly positive passenger experience.

\section{RECOMMENDATIONS}

Managers trying to create a delightful passenger experience should focus on the main airport dimensions (services and facilities, access procedures, environment, personnel) depending on the level of ascribed significance. Passengers are now accustomed to overcrowded airports and strict immigration and security procedures due to the many security risks facing the air transport industry nowadays. Thus, the way to delight passengers at airports will be to provide unconventional high quality services, a quiet and cheering environment and an efficient customer care staff.

- Airport managers must take into account the various socio-demographic characteristics of passengers (gender- age-education-frequency of air travel-occupation) in order to design an impressive customer experience. A unique customer experience must take into account the various passenger profiles with aim to create an airport experience that satisfies multiple segments.

- Managers at CIA seeking to improve the below average overall passenger experience must think beyond the conventional 'touch points'/moments of truth' concepts. Passengers seek a delightful airport experience that provides a unique ambiance, without neglecting the importance of other fundamental procedural elements (e.g. check-in - baggage claim) and basic services (e.g. retail shops-dining places). An above average experience is related to passenger's higher-order needs and wants (beyond their basic needs). The airport must offer: innovative, educational and relaxing activities; distinguished services and amenities; unique shopping and dining areas; special entertaining events.

- Results of the content analysis showed that CIA needs to primary invest its resources in the airport personnel development in areas of customer care and performance 
efficiency. A change in the customer care culture can surely enhance passengers' impressions and sentiments towards the overall experience.

- Moderators at CIA must focus on prohibiting any unnecessary contacts between workers and passengers throughout their journey in order to prevent negative interactions between both parties. More effort is needed in organizing queue lines and passenger movements throughout the airport.

- Investing into the 'smart airport' concept must be prioritized by the CIA management with an aim to provide a faster and more efficient passenger experience. The provision of self-service technologies at check-in and immigration check points is not enough. Airports must lure passengers to use automated services by promoting the ease, speed and efficiency of such technology-driven services. The airport technical staff and customer service personnel can play an effective role in this area.

- CIA managers should pay special attention to well established customer review sites (e.g. Sktrax) in order analyze passengers' impression and sentiments towards the airport experience. A content analysis of such online data can help draw a big picture of passengers' aspirations, sentiments and impressions towards the overall airport experience.

\section{FUTURE RESEARCH}

It is recommended that future research projects focus on conducting comparative studies between various airport experiences around the world. More research is needed with the aim explore the cultural uniqueness of passenger impressions and the characteristics of various successful innovations in many dimensions of the airport experience.

\section{REFRENCES}

1. Airffin, A.A.M., Yahaya, M.F. (2013). The relationship between airport image, national identity and passenger delight: A case study of the Malaysian low-cost carrier terminal (LCCT). Journal of Air Transport Management, Notes, 31, pp.33-36.

2. Airport Cooperative Research Program (2016) Improving the airport experience. Washington: Transportation Research Board, 157, pp.96-105.

3. Airport Council International (2016). Annual world airport traffic report, Montreal: ACI.

4. Bandeira, M. and Correia, A. (2012). Qualitative analysis of the relationship between the profile of departing passengers and their perception of the airport terminal, Journal of Air Transport Studies, 3(1), pp.78-102. 
5. Bogicevic, V. (2014). The effect of airport 'servicescape' of features on traveler anxiety and enjoyment. Unpublished thesis (Master), College of Hospitality and Technology Leadership, University of South of Florida.

6. Cairo Airport Authority (2017). Annual Statistical Report, Cairo: CAA.

7. Chakravorti, S. (2011). Managing organization culture change and knowledge to enhance customer experience: analysis and framework. Journal of Services Marketing, 19(2), pp.123-151.

8. Fodness, D. and Murray, B. (2007). Passenger's expectations of airport service quality. Journal of Services Marketing, 21(7), pp.492-506.

9. Gentile, C., Spiller, N. and Noci, G. (2007). How to sustain the customer experience: An overview of experience components that co-create value with customer, European Management Journal, 25(5), 397.

10. Halpern, N. and Graham, A. (2013). Airport marketing, UK: Routledge.

11. Hess, S., and Polak, J.W. (2005). Mix logit modelling of airport choice in multi-airport regions, -Journal of Air Transport Management, 11(2), pp.59-68.

12. Kalakou, S. Psaraki-kalouptsidi, V., and Moura, F. (2015). Future airport terminals: new technologies promise capacity gains. Journal of Air Transport Management, 42, pp.203-212.

13. Kamarudin, R. (2015). Managing Customer Expectation for Passenger Service at Airport, Hong Kong: ACI Asia Pacific, pp.1-17

14. Losekoot, E. (2015). A case study of Auckland International Airport's customers. Unpublished thesis (Ph.D.), Auckland University of Technology.

15. Lubbe, B., Douglas, A., \& Zambellis, J. (2011). An application of the airport service quality model in South Africa. Journal of Air Transport Management, 17, pp.224-227.

16. Mckinsey (2016). Customer experience: creating value through transforming customer journeys. US: Mckinsey, pp.35-36.

17. Minton, H. (2008). Waiting and queuing in the check-in hall: an ethnographic study of queuing and waiting for check-in services at Manchester Airport. Journal of Airport Management, 2(3), pp.249-264.

18. Mukerjee, K. (2012). Customer experience management: A framework for successfully managing the customer experience, Prespectiva: $A$ case research journal, 4, pp.1-11.

19. Oum, T. H., Yu, C., \& Fu, X. (2003). A comparative analysis of productivity performance of the world's major airports: summary report of the ATRS global airport benchmarking research report 2002. Journal of Air Transport Management, 9, pp.285-297. 
20. Ranaweera C., \& Prabhu J. (2003). On the relative importance of customer satisfaction and trust as determinants of customer retention and positive word of mouth, Journal of Targeting, Measurement and Analysis for Marketing, 12(1), pp.82-98.

21. Rawson, A., Duncan, E. and Jones, C. (2013). The truth about customer experience. Harvard Review, September. Available from: https://hbr.org/2013/09/the-truth-aboutcustomer-experience (Accessed 10/3/17).

22. Ritchie, J. and Goeldner, C. (1994) Travel, tourism and hospitality research: a handbook for managers and researches, 2nd ed., John Wiley.

23. Samy, H. (2016). Analyzing the social media marketing content of leading Arab Airports, The Journal of Arab Universities for Tourism and Hotels, 14(1), accepted for publication.

24. Samy, H. (2016). Studying traveler's use of self-check-in technologies at smart airports, The Journal of Arab Universities for Tourism and Hotels, 13(2), accepted for publication.

25. Siebert, L., Kasarda, J. (2008). Airport cities: the evolution, England: Insight Media.

26. Skytrax (2017). Best airports by world region. Available from: http://www.worldairportawards.com/Awards/best_airports_by_world-region (accessed on 12/4/17).

27. Sprinklr (2015). The survival guide to customer experience. New York: Sprinklr, p.8.

28. Verhoef, P. et al. (2009). Customer experience creation: determinants, dynamics and management strategies, Journal of Retailing, 85, pp.31-41.

29. Widarsyah, R. (2013). The impact of airport service quality dimension on overall airport experience and impression. Unpublished thesis (Master), University of Nevada Las Vegas.

30. Wiredja, D., Popvic, V. and Blackler, A. (2015). Questionnaire design for airport passenger experience survey, US: International Association of Societies of design research, pp.1-16 